\title{
PENANGGULANGAN PENCEMARAN LINGKUNGAN MELALUI PKM UKM TAHU DAN TEMPE DENGAN PEMANFAATAN LIMBAH INDUSTRI
}

\author{
Lusiana',Puryantoro ${ }^{2)}$ \\ ${ }^{1}$ Fakultas Ekonomi, Universitas Abdurachman Saleh, Situbondo \\ Email : lusianatulhusnah17@gmail.com \\ ${ }^{2}$ Fakultas Pertanian, Universitas Abdurachman Saleh, Situbondo \\ Email : puryantorounars@gmail.com
}

\begin{abstract}
Community service aims to provide partners with the skills and knowledge to utilize tofu liquid waste to be organic fertilizer and provide assistance in making chimney smoke. This activity uses continuous training and mentoring methods to achieve the target of the solutions offered. During the activity the participants followed very enthusiastically and were committed to developing the production of organic fertilizer from liquid waste knowing to be a side business and a superior village product. In addition, smoke puffs which become a social problem for residents around the tofu industry have been handled by making chimneys.
\end{abstract}

Keywords: environmental pollution, liquid waste, tofu industry

\begin{abstract}
Abstrak: Pengabdian kepada masyarakat ini bertujuan untuk memberikan keterampilan dan pengetahuan kepada mitra untuk memanfaatkan limbah cair tahu menjadi pupuk organik dan memberikan pendampingan pembuatan asap cerobong. Kegiatan ini dengan menggunakan metode pelatihan dan pendampingan berkesinambungan sehingga tercapai target dari solusi yang ditawarkan. Selama kegiatan berlangsung peserta mengikuti sangat antusian dan berkomitmen untuk mengembangkan produksi pupuk organik dari limbah cair tahu mejadi usaha sampingan dan produk unggulan desa. Selain itu kepulan asap yang menjadi masalah sosial warga sekitar industri tahu telah tertangani dengan dibuatnya cerobong asap.
\end{abstract}

Kata kunci : pencemaran lingkungan, limbah cair, industri tahu

\section{PENDAHULUAN}

Perkembangan industri di
Indonesia saat ini menunjukkan
terjadinya kemajuan pesat dibidang
ekonomi. Perkembangan ini tidak hanya
terjadi di skala industri besar tetapi juga
terus merambah sampai di tingkat
industri kecil seperti industry rumah
tangga (home industry). (Rohmansyah,
2017). Di lain pihak, dampak negatif
juga terjadi seperti makin banyaknya
limbah yang dihasilkan dari industri- industri yang tidak dapat dihindari sehingga akan berdampak terjadinya pencemaran lingkungan. Untuk menanggulangi masalah pencemaran lingkungan, masyarakat harus mulai berpikir keras untuk memanfaatkan limbah industri yang masih dapat dimanfaatkan. Hal ini akan mengurangi biaya pengolahan limbah dan secara tidak langsung akan menambah pendapatan atau penghasilan bagi masyarakat. (Iftitah, Yekti, \& Suryaningsih, 2017) 
Vol. 1, No. 2, Jul 2018, hlm. 91 - 94

Available online at http://jurnal.stmikroyal.ac.id/index.php/jurdimas

Desa Juglangan Kecamatan Panji Kabupaten Situbondo merupakan salah satu kawasan industri rumah tangga tahu tempe. Industri tahu di Desa Juglangan pun tak lepas dari permasalahan tentang limbah yang dihasilkan. Pabrik tahu dalam proses pengolahannya menghasilkan limbah, baik limbah padat yang dihasilkan penyaringan dan penggumpalan, limbah ini kebanyakan oleh pengrajin dijual dan diolah menjadi tempe gembus. Sedangkan limbah cairnya dihasilkan dari proses pencucian, perebusan, pengepresan dan pencetakan tahu, oleh karena itu limbah cair yang dihasilkan sangat tinggi. Limbah cair tahu dengan karakteristik mengandung bahan organic tinggi dan kadar BOD, COD yang cukup tinggi pula, jika dibuang langsung ke saluran air akan menurunkan daya dukung lingkungan. Sehingga industri tahu memerlukan suatu pengolahan limbah yang bertujuan mengurangi pencemaran lingkungan yang ada. Dampak lingkungan lainnya adalah menimbulkan pencemaran udara dari asap pengolahan tahu, asap dari kayu bakar. Kepulan asap pada industri tahu mitra pengabdian dikarenakan masih belum diatasi dengan pembuatan cerobong sehingga asap menyebar ke rumah sekitar industri tahu.

Berdasarkan analisis situasi di atas, mitra kurang memahami pemanfaatan limbah cair ampas tahu dan terbatasnya modal untuk membuat cerobong asap. Sehingga perlu diadakannya pengabdian kepada masyarakat untuk memberikan keterampilan dan pengetahuan dalam memanfaatkan limbah cair industry tahu dan memberikan pendampingan pembuatan cerobong asap.

\section{METODE}

Mengatasi permasalahan mitra industri tahu Desa Juglangan Kecamatan Panji harus secara tepat guna dengan memperhitungkan hal hal seperti efisien, efektif, dan terpadu agar dapat meningkatkan kesejahteraan dan keberlanjutan usaha yang telah dirintis pengrajin tahu. Metode pendekatan yang akan dilakukan berdasarkan kesepakatan dengan mitra adalah:

1) Pelatihan untuk meningkatkan keterampilan mitra untuk memanfaatkan limbah cair menjadi pupuk organic.

2) Pendampingan pembuatan cerobong asap.

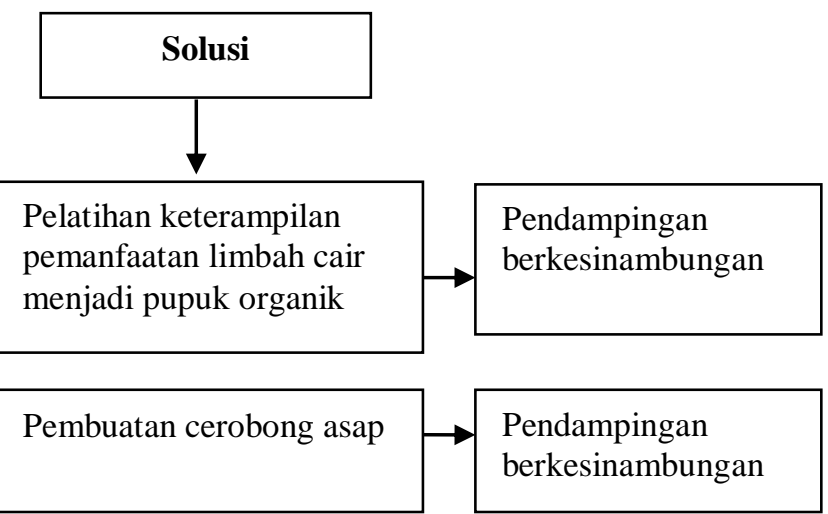

Gambar 1. Metode Pelaksanaan Kegiatan PKM 
Vol. 1, No. 2, Jul 2018, hlm. 91 - 94

ISSN 2614-7912 (cetak)

ISSN 2622-3813 (online)

Available online at http://jurnal.stmikroyal.ac.id/index.php/jurdimas

\section{PEMBAHASAN}

Ada beberapa hasil yang dicapai dalam penerapan PKM UKM tahu tempe dengan mitra pengabdian UKM tahu tempe Bapak Rasyidi dan Ibu Dewi di Desa Juglangan kecamatan Panji Kabupaten Situbondo 1. Pembuatan Cerobong Asap

Keluhan warga sekitar industri tahu adalah kepulan asap hingga ke rumah warga yang menggangu terlebih ketika musim kemarau biasanya angin barat menyebabkan gangguan pernafasan. Hal tersebut dikarenakan belum dibangunnya cerobong asap oleh mitra. Tanggal 9-20 April 2018dilakukan pembuatan cerobong asap.

Dengan dibuatnya cerobong asap tidak lagi masuk ke rumah warga sehingga aktifitas warga sekitar industry tidak tengganggu.

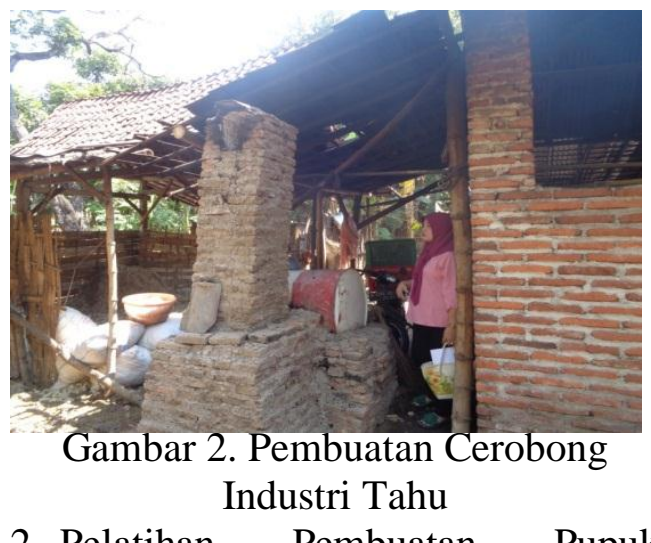

2. Pelatihan Pembuatan Pupuk Organik Limbah Cair Industri Tahu

Limbah tahu ditambah dengan bahan tambahan lainnya dapat dipakai sebagai pupuk organik melalui proses fermentasi sehingga bahan aktif dapat terurai dengan baik. Limbah cair tahu mengandung sisa protein dan asam cuka sehingga mampu mendukung efektifitas fermentasi. Tanggal 28 Juni 2018 dilakukan sosialiasi kandungan dan cara pembuatan pupuk organik dari limbah cair tahu.

Bahan yang digunakan :

1. Air limbah tahu

2. Air kelapa

3. Alkohol $70 \%$

4. Temulawak

5. Sereh

6. Dekomposer (EM)

Cara pembuatannya

1. Bahan herbal temulawak dan sereh dihancurkan dengan diblender atau digiling.

2. Masukkan bahan herbal ke dalam air limbah tahu lalu tambahkan alkohol dan air kelapa.

3. Masukkan decomposer (EM).

4. Tutup dan simpan selama 10 hari.

5. Bila larutan berbau menyengat menandakan fermentasi yang sempurna.

Cara penggunaan ; 1 liter bahan dilarutkan dengan 10 liter air kemudian disemprotkan ke tanaman.

Menurut murdani (2010) pupuk limbah cair tahu dicampur dengan bahan herbal terbukti secara efektif membasmi serangan jamur spedomonas dan tanaman menjadi hijau. Luran dari kegiatan ini adalah pupuk cair organik dari limbah cair tahu yang nantinya dapat menjadikan usaha baru atau usaha sampingan bagi masyarakat desa Juglangan.

\section{SIMPULAN}

Kegiatan pengabdian selama 2 bulan di Desa Juglangan Kecamatan Panji berjalan sesuai jadwal yang ditentukan bersama dengan mitra. Antusias mitra selama mengikuti kegiatan sangat baik bahkan mitra mengharapkan kegiatan serupa untuk menangani masalah mitra lainnya yang belum terprogram dalam 
Vol. 1, No. 2, Jul 2018, hlm. 91 - 94

ISSN 2614-7912 (cetak)

ISSN 2622-3813 (online)

Available online at http://jurnal.stmikroyal.ac.id/index.php/jurdimas

kegiatan ini. Permasalahan mitra mengenai pencemaran lingkungan dari limbah cair industri tahu dan asap telah diselesaikan dengan baik. Mitra telah mengetahui dan terampil memanfaatkan limbah cair tahu menjadi pupuk organik. Sementara asap yang dikeluarkan oleh industri tahu dalam proses pembakaran selama produksi tahu telah diatasi dengan pembuatan cerobong asap.

\section{UCAPAN TERIMAKASIH}

Mengucapkan terimakasih kepada :

1. Direktorat Riset dan Pengabdian kepada Masyarakat, Direktorat Jenderal Penguatan Riset dan Pengembangan-Kementerian Riset, Teknologi, dan Pendidikan Tinggi Republik Indonesia atas bantuan dana melalui program Pengabdian kepada Masyarakat Skim Program Kemitraan Masyarakat Tahun Anggaran 2018

2. Rektor Universitas Abdurachman Saleh Situbondo bersama jajarannya serta rekan- rekan tim pengabdi di Universitas Abdurachman Saleh serta berbagai pihak yang turut membantu terlaksananya program pengabdian pada masyarakat ini.

3. Pusat Penelitian dan Pengabdian kepada Masyarakat Universitas Abdurachman Saleh yang selalu memberikan semangat agar dosen rajin untuk melaksakan kegiatan Tridharma Perguruan Tinggi.

\section{DAFTAR PUSTAKA}

Iftitah, G., Yekti, A., \& Suryaningsih, Y. (2017). Pelatihan Pembuatan Cookies dari Ampas Tahu Bagi Masyarakat Kelurahan Ardirejo Sebagai Upaya Pemanfaatan Limbah Padat Pembuatan Tahu. Jurnal Paradharma 1, 1(April 2017), 2834.
Rohmansyah,N.Aziz., Nurdyansyah,Fafa., \& Kusuma,Bertika. Pemberdayaan Masyarakat Melalui IbM Pelatihan Olahan Limbah Tahu Di Desa Drono Ngawen Klaten. JKB 21, XI (Desember 2017), (42-48)

Murdani.2010. "Membuat Pupuk dan Pestisida Organik dari Limbah Tahu".

www.bbppketindan.bppsdmp.pertanian.go .id diakses tanggal 20 Juli 2018. 